\title{
OPEM
}

www.opem.org

Oriental Pharmacy and Experimental Medicine 2010 10(3), 184-190

DOI 10.3742/OPEM.2010.10.3.184

\section{Pharmacognostic evaluation of the roots of Berberis lycium royle}

\author{
Sharad Kumar Srivastava*, Ajay Kumar Singh Rawat and Shanta Mehrotra \\ Pharmacognosy \& Ethnopharmacology Division, National Botanical Research Institute, Lucknow-226001, India
}

Received for publication January 23, 2008; accepted September 7, 2010

\begin{abstract}
SUMMARY
Berberis lycium (family Berberidaceae) has a close affinity with B. aristata, used in India Traditional Systems of Medicine as a drug 'Daruharidra' for skin disease, jaundice, affection of eyes, and rheumatism. Various species of Berberis are being sold in India herbal drug market. During the market surveillance of different herbal drug markets of India, it was observed that almost all the markets either comprise of Berberis lycium or Berberis asiatica. Keeping this in view, in the present study attempts have been made to identify marker characters of this potent species.
\end{abstract}

Key words: Berberis lyceum; HPTLC; Daruharidra; Substitute

\section{INTRODUCTION}

Some of the diagnostic features of the root are patches of pericyclic fibre, pitted sclerieds and berberine containing cells and heterocyclic medullary rays. Besides, the physicochemical characters such as total ash; acid insoluble ash; alcohol and water soluble extractive; tannins; sugar and starch percentages has shown variations. The percentage of berberine as berberine hydrochloride was also calculated through HPTLC densitometric method and it was found almost in similar range to $B$. aristata, $B$. asiatica and B. chitria i.e. $2.45 \%$. Thus this data can be utilized by the pharmacologist to explore the possibilities of this species as substitute to Daruharidra.

Berberis lycium Royle is an important medicinal plant belonging to family Berberidaceae. It is very common in different markets of India as an adulterant/substitute to 'Daruharidra' i.e. B. aristata.

*Correspondence: Sharad Kumar Srivastava, Pharmacognosy \& Ethnopharmacology Division, National Botanical Research Institute, Lucknow-226001, India. E-mail: sharad_ks2003@yahoo.com, sharad_ks@hotmail.com
The root are used for treating a variety of ailments such as eye and ear diseases, rheumatism, jaundice, diabetes, fever, stomach disorders, skin disease, malarial fever and as tonic(Watt, 1883; Kirtikar and Basu, 1933; Chopra et al 1958; Anonymous, 1988). Its use in the management of infected wounds has also been described in Ayurvedic classical texts (Sushrut Samhita, 1963).

Major alkaloid of the plant is berberine, which is known for its activity against cholera (Dutta and Panse, 1962), acute diarrhea (Lahiri and Dutta, 1967), amoebiasis, latent malaria and for the treatment of oriental sore caused by Leishmania tropica (Anonymous, 1988).

Over exploitation of $B$. aristata by different pharmaceutical industries created scarcity of the material that opened new vistas to identify a possible substitute for this species. During market surveillance of different herbal drug markets of India, it was observed that almost all the markets either comprise of Berberis lycium or Berberis asiatica. Although a detailed pharmacognostic study of $B$. aristata, B. asiatica and B. chitria is reported by 
Srivastava et al., (2001, 2004, and 2006), but till date no pharmacognostic details are available on B. lycium. Hence, the present study has been undertaken, which may be useful to pharmaceutical industries for the authentication of the commercial samples and to explore the possibilities of using this species as a substitute of B. aristata.

\section{MATRIALS AND METHODS}

Plant material was collected from the Dhanaulti (Uttaranchal) region of India, authentication was done by Dr. AKS Rawat through matching the specimen in our National herbarium and a voucher specimen was deposited [LWG 221238, 1998]. Roots were preserved in 70\% ethyl alcohol for histological studies. Microtome sections were cut and stained with safranin and fast green and photographed with Nikon F70X camera (Johansen, 1940). Physicochemical and phytochemical studies like, total ash, acid insoluble ash, tannins and total alkaloids were calculated from the shade dried powdered material according to the recommended procedures (Peach and Tracy, 1955; Anonymous, 1965; Siwon et al., 1980; Anonymous 1984). Behavior of the powdered drug with different chemical reagents was also studied as per methods described by Chase and Pratt (1949) and Kokoski et al. (1958).

\section{RESULTS AND DISCUSSION}

\section{A brief taxonomic description of the plant}

An evergreen shrub usually $1.2-1.8 \mathrm{~m}$ high, but sometimes attaining a height of $3.6 \mathrm{~m}$ with $10 \mathrm{~cm}$ diameter; twigs pale yellowish, glabrous or minutely pubescent; bark rough and rather deeply furrowed; blaze $5 \mathrm{~mm}$ bright yellow with coarse reticulate fibre; leaves $2.5-7.5 \times 0.7-1.8 \mathrm{~cm}$, lanceolate or narrowly obovate-oblong, coriaceous, entire or with a few large spinous teeth, dull green above, pale and glaucous beneath, secondary nerves not prominent on the upper surface; petioles absent or distinct up to $2.5 \mathrm{~mm}$; inflorescence a simple raceme, 13 - $38 \mathrm{~mm}$ long, often with a few longstalked flowers at the base; pedicels slender, green 5 - $13 \mathrm{~mm}$ long; fruit ellipsoid to ovoid, $7 \mathrm{~mm}$ long, blue or black; style distinct.

\section{Macroscopic characters of the root}

Roots are woody, grayish white, cylindrical, with smooth surface and thin brittle bark. Cut surface deep yellow. The main features distinguishing it from other species are a smooth surface of grayish white colour and a deep yellow wood. Fracture hard; odour phenolic; taste bitter (Fig. 1).

\section{Microscopic characters of the root}

Transverse section is circular and regular in outline. Layers of cork, which forms outer most zones, is thin walled, suberized, dark brown and composed of 8 to 11 layers of rectangular cork cells. Following cork layers, 2 or 3 layers of cork

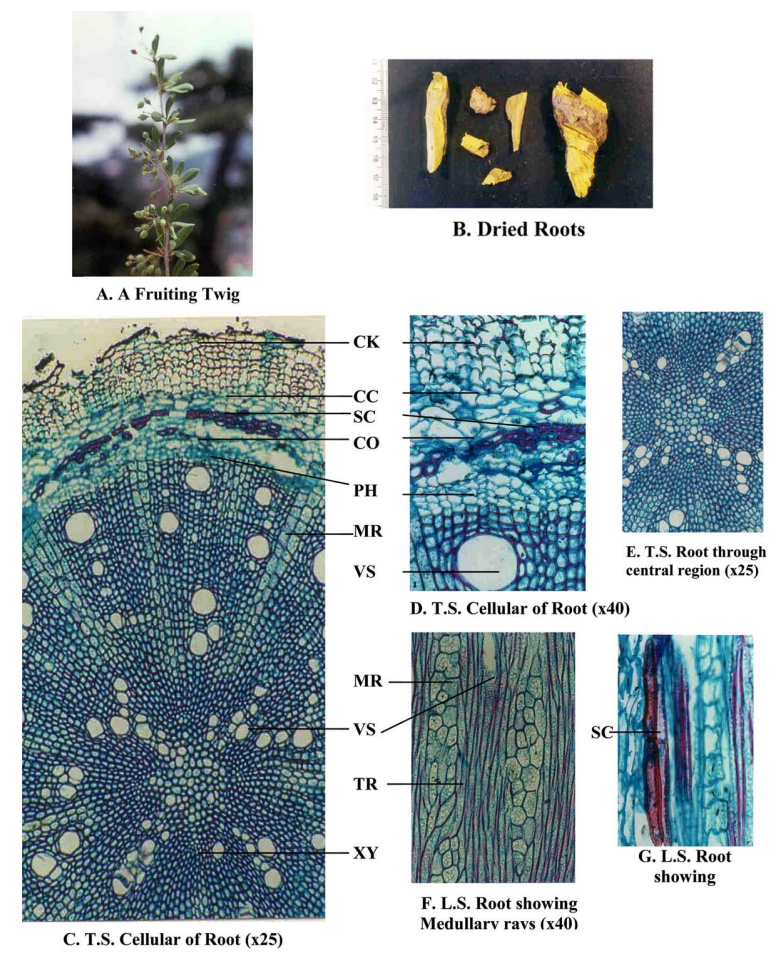

Fig. 1. Macroscopic \& Microscopic characters of Berberis lycium root. CC, Cork cambium; CK, Cork cells; CO, Cortex; MR, Medullary ray; PH, Phloem; SC, Sclereids; VS, Vessels; XY, Xylem. 
cambium is present. Cortical zone is secondary in nature and composed of 17 to 22 layers of rectangular parenchymatous cells. Sclerieds are frequently present in cortical zone and are of 2 to 4 in groups. Frequent patches of sclerenchymatous pericyclic fibres have also been observed in this region. Cells filled with tannins and starch grains are also seen. Pericyclic fibre patches are comparatively lesser in number than other species. Presences of berberine containing cells are clearly visible. Following the cortical zone is secondary phloem region, which is 4 to 6, cells deep. Vessels distinct distributed among xylem fibres, solitary or sometimes ingroups of 2 or 3; tracheids and fibres are present. Vessels and tracheids occupy central zone (Fig. 1). In transverse longitudinal section, rays are heterogenous, 2 to 5 cells broad, pitted and filled with starch grains and alkaloidal content (Fig. 1).

\section{Measurement of macerated elements}

On maceration, the vessels $(140.108 \times 24.629 \mu \mathrm{m})$ with annular, reticulate, spiral, scalariform and some with simple pits are observed and tailed vessels are also observed. The trachieds with bordered pits measuring $282.836 \times 12.603 \mu \mathrm{m}$ and tracheidal fibres $368.931 \times 12.218 \mu \mathrm{m}$ and simple fibres $517.879 \times 10.884 \mu \mathrm{m}$ are clearly discernible.

\section{Study of powder}

On microscopic examination the powder revealed the presence of fragments of rectangular cork cells, cortical parenchymatous cells, pericyclic fibres, stone cells, spiral, pitted and reticulate vessels, tracheids with bordered pits and starch in single or compound grains.

The behavior of the powdered drug with different chemical reagents was also studied as per standard methods. Powder when treated with $1 \mathrm{~N}-\mathrm{HCl}$ and nitrocellulose in amyl acetate emits fluorescence yellow colour under UV 254.

\section{Physico-chemical Studies}

Air-dried material was used for quantitative determination of different physico-chemical values and other phytochemical investigations. The values obtained are presented in Fig. 2.

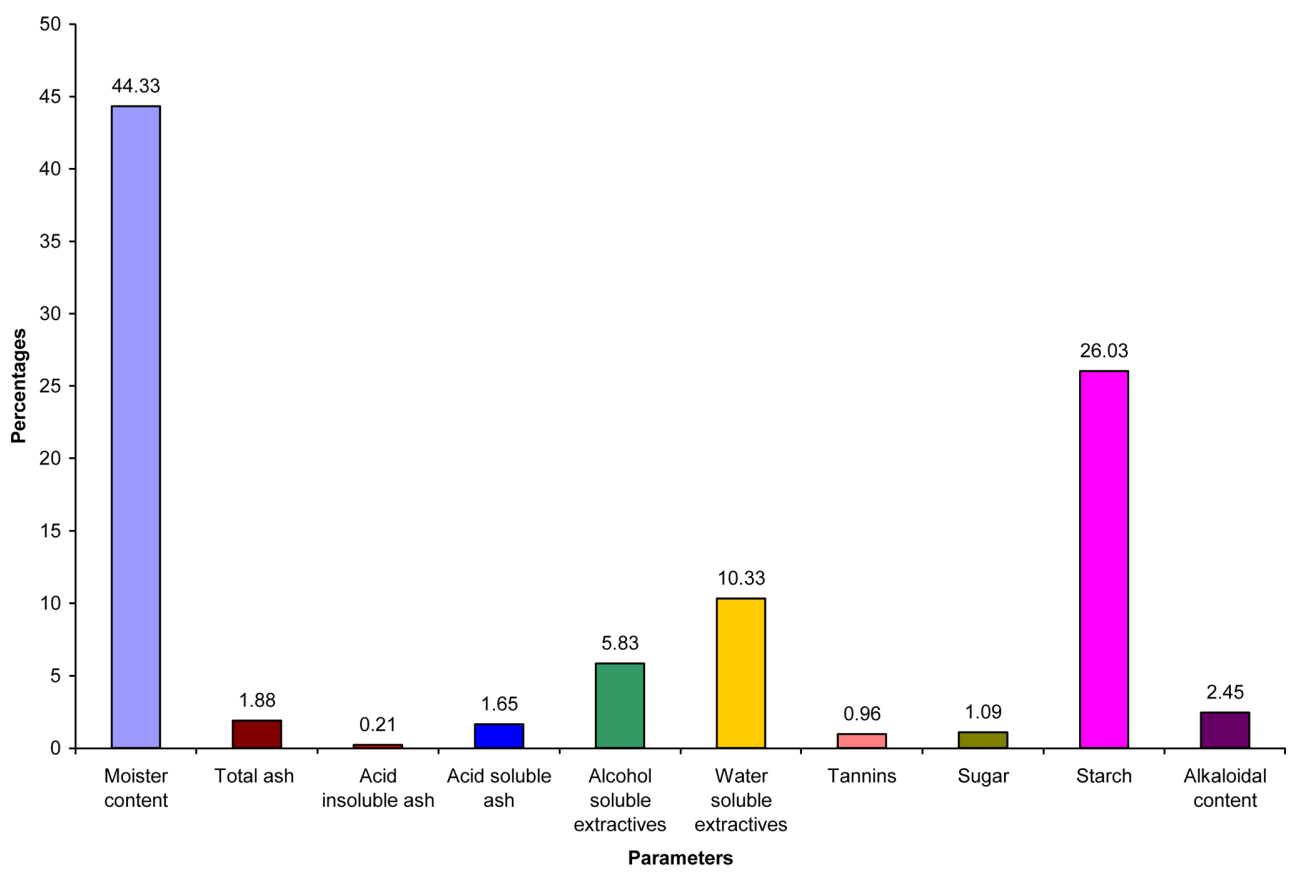

Fig. 2. Physico-chemical values of B. lycium root. 


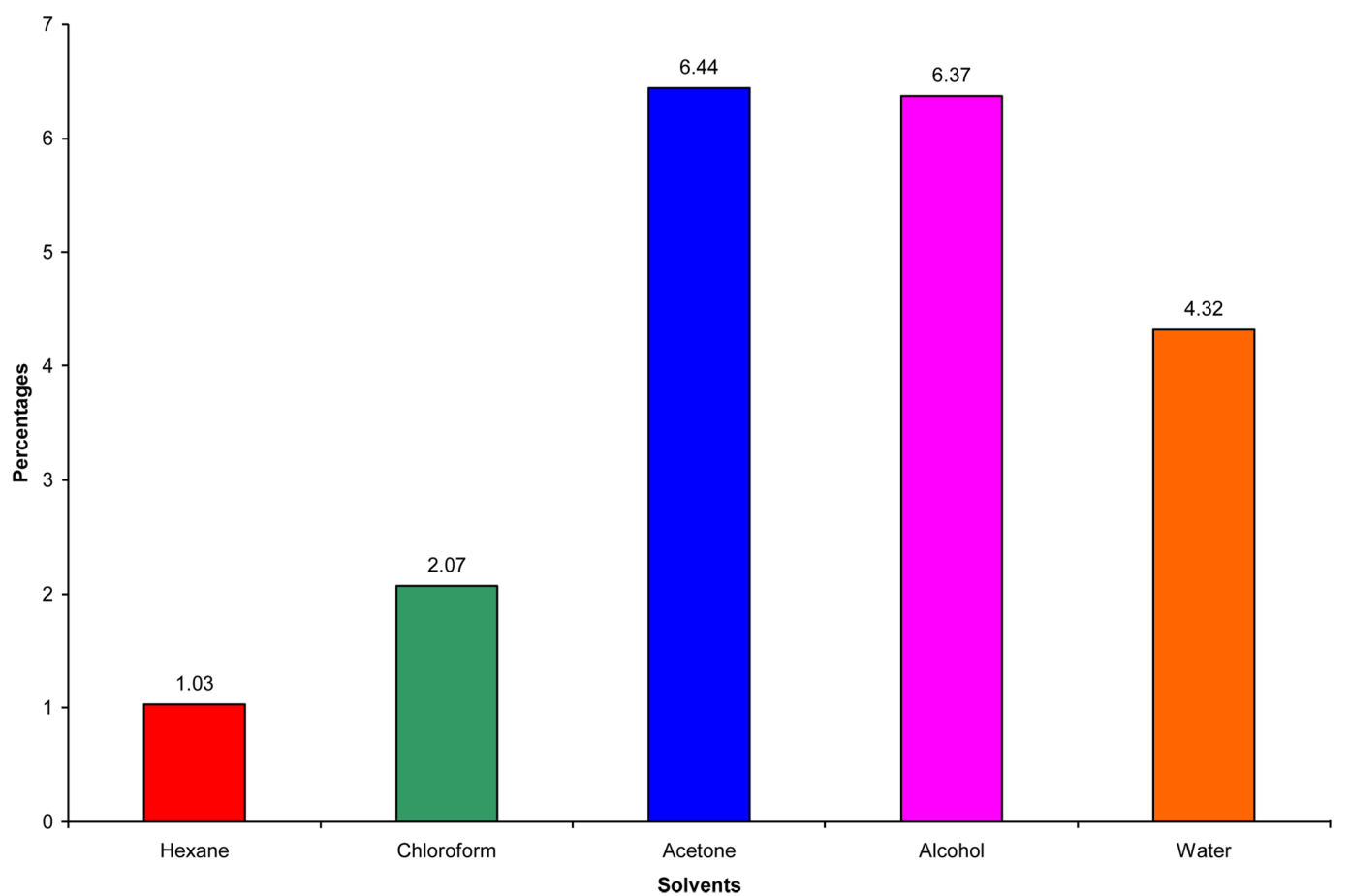

Fig. 3. Successive Soxhlet extractive values of B. lycium root.

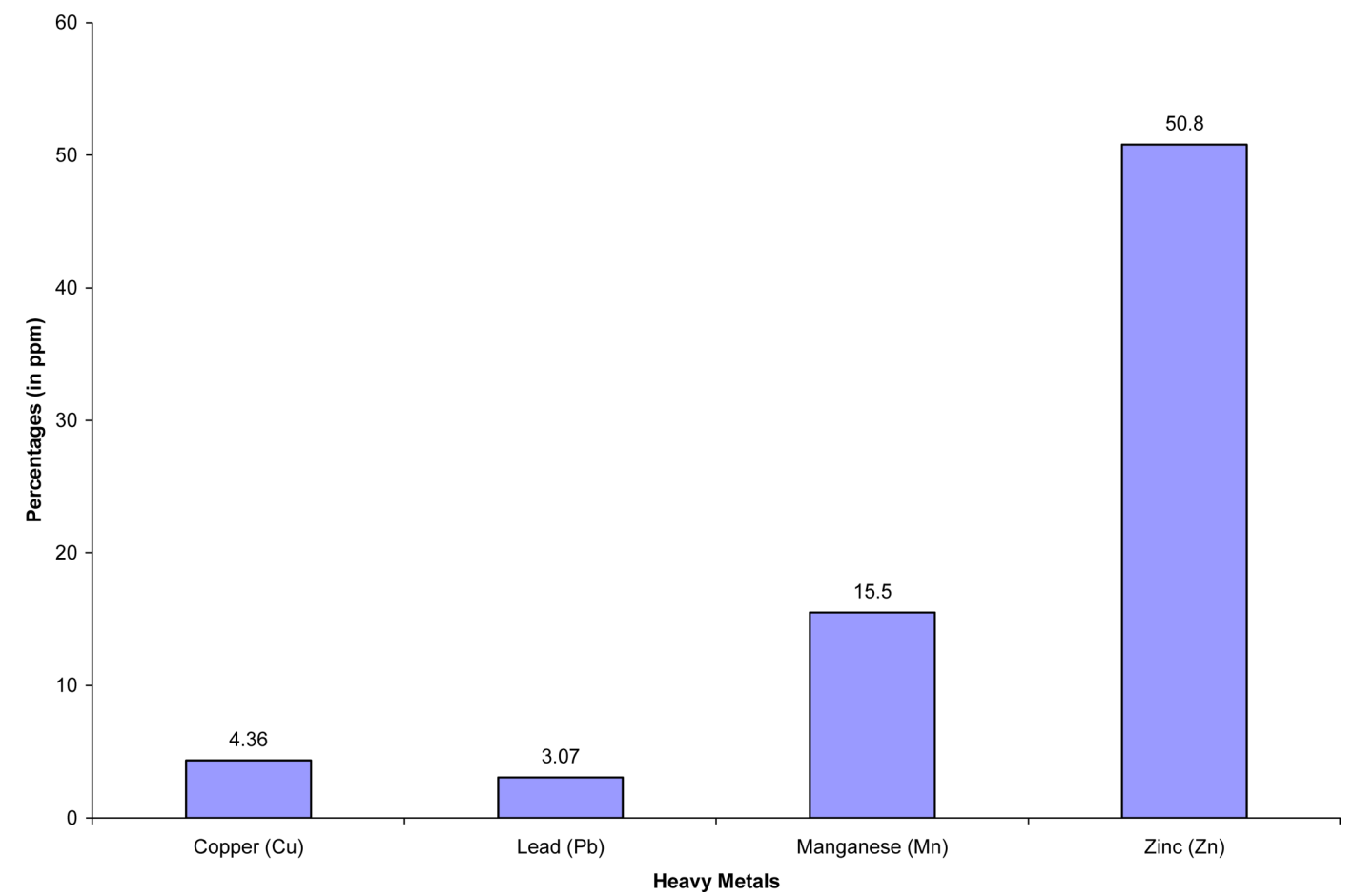

Fig. 4. Heavy Metal studies of B. lycium root. 
$2 \mathrm{gm}$ of dried root powder was extracted in Soxhlet with hexane, chloroform, acetone, alcohol and water successively and percentage was calculated (Fig. 3) and tested for different constituents namely steroids and triterpenoids (LB test), flavonoids (Shinodas test), alkaloids (Mayer's reagent), tannins (ferric chloride test) and sugar (Fehling solution test). The study revealed that the triterpenoids are present in hexane and chloroform soluble parts, tannin is only in water soluble part while the resin present in acetone and alkaloids in chloroform, acetone, alcohol and water soluble parts.

\section{HPTLC studies}

A densitometric HPTLC analysis was also performed for the development of characteristic fingerprint profile, which may be used as markers for quality evaluation and standardization of the drug. In addition the study also explores the possibilities for using this species as a substitute of B. aristata. 1 gm powdered root was refluxed for $5 \mathrm{~min}$ on water bath with $5 \mathrm{ml}$ methanol consequently three times, filtered and filtrate taken as test solution along with reference berberine ( $7 \mu \mathrm{l}$ of each) and was applied on HPTLC precoated silicagel G60 $\mathrm{F}_{254}$ Merck glass plates of $20 \times 10 \mathrm{~cm}$ with the help of Camag Linomat-IV applicator and eluted the plate to a distance of $6.20 \mathrm{~cm}$ at room temperature $\left(19^{\circ} \mathrm{C}\right)$ in solvent system $\mathrm{n}$-propanol : water : formic acid (90 : $8.0: 0.4)$. The bands in the sample are obtained at

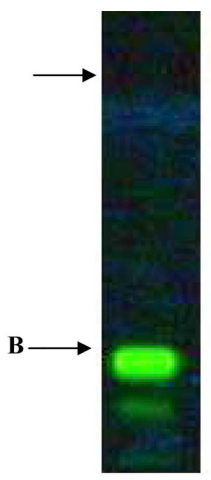

Ref

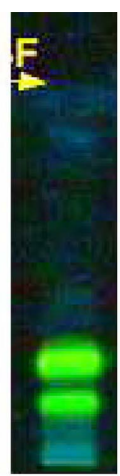

R1

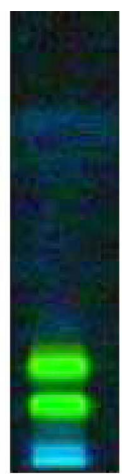

R2

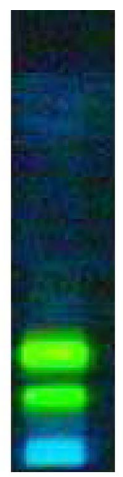

R3

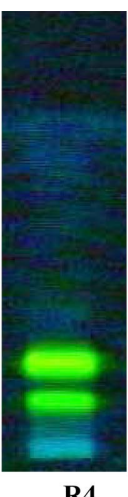

R4
Fig. 5. HPTLC Profile of Berberis lycium, allied species and reference sample (Under UV- 366).
$\mathrm{R}_{\mathrm{f}} \mathrm{s} 0.06,0.20$ and 0.32 , which can be used as identifying markers. Berberine was identified at $R_{f}$

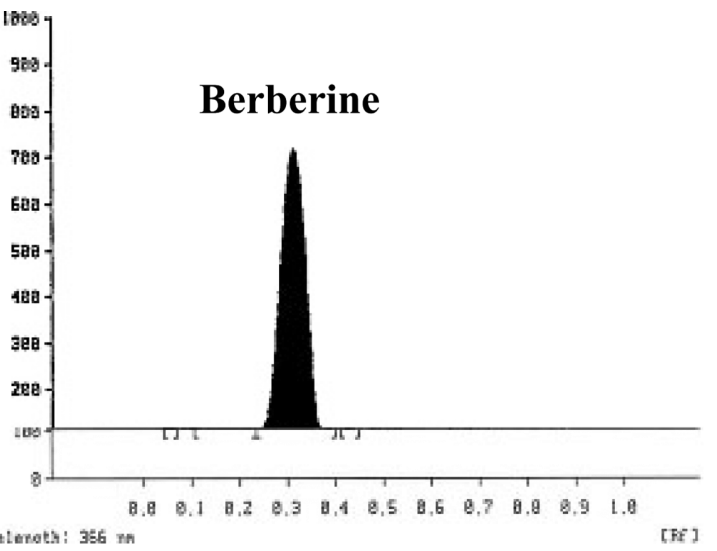

Fig. 6. Chromatogram of reference sample.

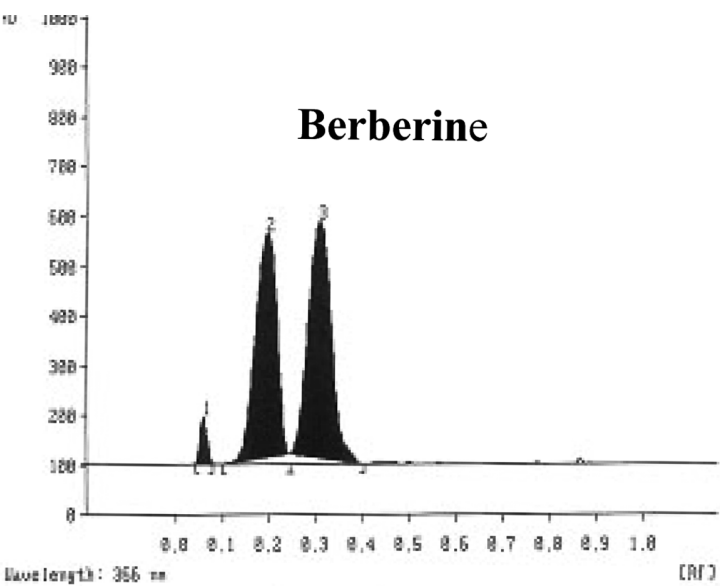

Fig. 7. Chromatogram of B. aristata Root.

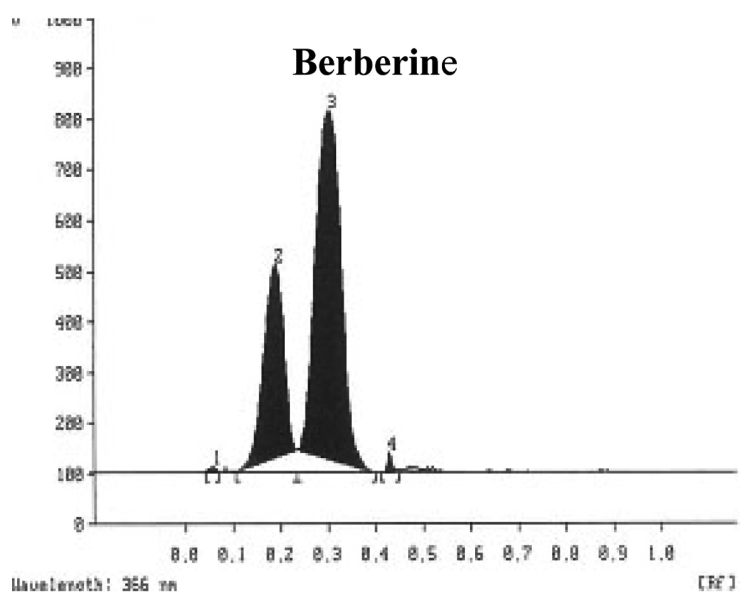

Fig. 8. Chromatogram of B. asiatica Root. 


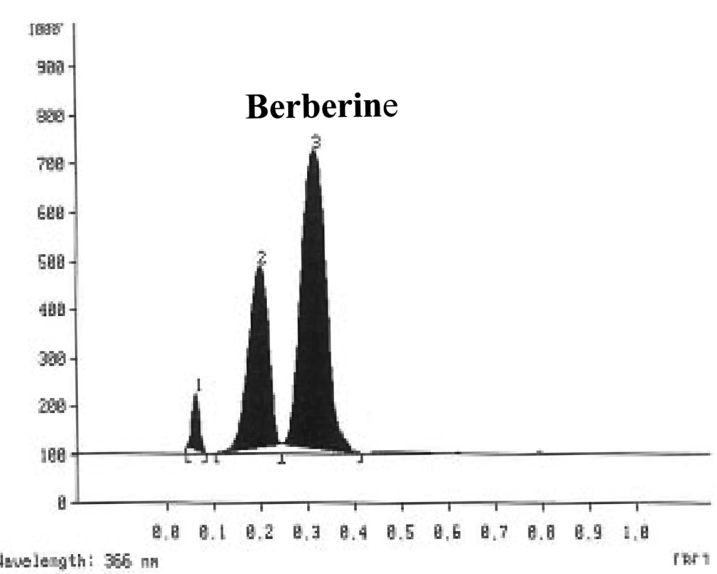

Fig. 9. Chromatogram of B. chitria Root.

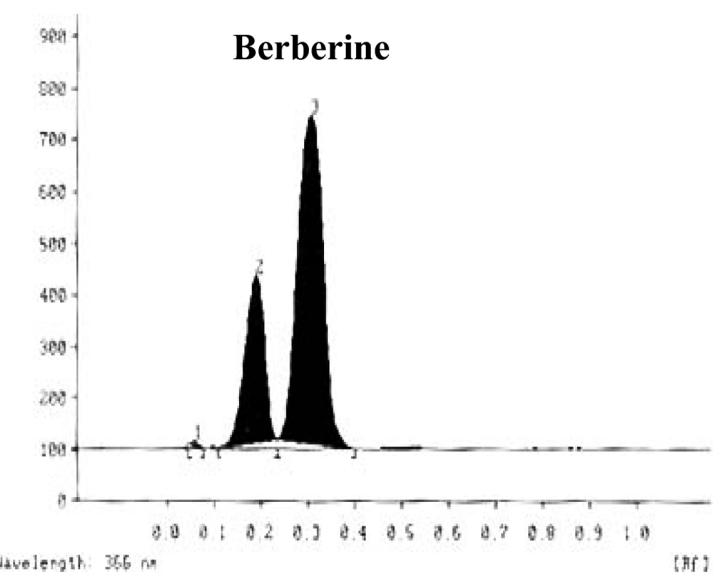

Fig. 10. Chromatogram of B. lycium Root.

0.32 (Fig. 4-9).

\section{Heavy metal studies}

A heavy metal analysis was also done to check the quality of toxic metals in the root (Fig. 4).

\section{CONCLUSION}

From the ongoing descriptions it is revealed that $B$. lycium could be identified on the basis presence of patches of pericyclic fibre, pitted sclerieds, berberine containing cells and heterocyclic medullary rays. On the contrary, the chemical profile of all the three species i.e. B. aristata, B. asiatica and B. chitria are almost identical (Srivastava et al. 2001, 2004, and 2006) with that of B. lycium. Therefore B. lycium can be explored as a substitute of B. aristata.

\section{ACKNOWLEDGEMENTS}

The senior author is thankful to Director NBRI for his encouragement and advice during the work.

\section{REFERENCES}

Annonymous (1988) The wealth of India Berberis Linn. (Berberidaceae). Ed Ambastha Sp Publication and Information Directorate, CSIR, New Delhi, India. 2B, pp. 114-118.

Anonymous (1965) Indian Pharmacopoeia, $2^{\text {nd }}$ Edn. Govt. of India; New Delhi 38-40.

Anonymous (1984) Official methods of Analysis (AOAC) $4^{\text {th }}$ Edn. Association of Official Chemists, Inc. U.S.A. 55-56.

Chase CR and Pratt RJ (1949) Fluorescence of Powdered vegetable drugs with particular reference to development of a system of identification. J. Am. Pharm. Assoc. 38, 324-331.

Chopra RN, Chopra TC, Handa KL, Kapoor LD. (1958) Chopra's Indigenous Drugs of India, 284. U.N. Dhar and sons Pvt. Ltd. 503-505.

Dutta NK and Panse MV. (1962) Usefulness of berberine (an alkaloid from Berberis aristata) in the treatment of cholera. Indian J. Med. Res. 732-735.

Johansen DA (1940) Plant Micro Techniques 182, McGraw Hill Book Co. Inc., New York 102-104.

Kirtikar KR and Basu BD (1933) Indian. Medicinal. Plants. I, Lalit Mohan Basu and Co., Allahabad, 2422-2423.

Kokoski J, Kokoski R, Slama FJ. (1958) Fluorescence of powdered vegetable drugs under ultraviolet radiation. J. Amer. Pharmacol. Assoc. 75-77.

Lahiri SC and Dutta NK. (1967) Berberine and chloramphenicol in the treatment of cholera and severe diarrhoea. J. Ind. Med. Assoc. 1-11.

Peach K and Tracy MV. (1955) Modern Methods of Plant Analysis (Heidelberg : Springer) $3^{\text {rd }}$ and $4^{\text {th }}$ vol.: 258-261.

Srivastava SK, Khatoon S, Rawat AKS, Mehrotra S, Pushpangadan P. (2001) Pharmacognostical studies of the roots of Berberis aristata DC. Natural Product Sciences 7, 102-106.

Srivastava SK, Rawat AKS, Mehrotra S. (2004) 
Pharmacognostic Evaluation of the Root of Berberis asiatica Roxb. ex DC. Pharmaceutical Biology 42, 467-473. Srivastava SK, Rawat AKS, Srivastava M, Mehrotra S. (2006) Pharmacognostical studies of the roots of Berberis chitria Lindl. Natural Product Sciences 12, 19-23. Siwon J, Verpoorte R, Van Essen GFA, Baerhem A, Vendson S. (1980) Studies on Indonesia Medicinal
Plants. Planta. Medica. 24-32.

Sushrut Samhita. 1963. Sutrasthanam Lakshadi Group. Ed Bhishagratna KK, Chaukhamba Sanskrit Sansthan, Varanasi, India 1, 354.

Watt G. (1883) Economic products of India V, The superintendent of Government Printing, India 652653. 